\title{
MiSeq Sequencing Analysis of Bacterial Community Structures in Wastewater Treatment Plants
}

\author{
Yun Wen*, Yunxiao Jin, Jiayang Wang, Lipeng Cai \\ Department of Civil Engineering, Luoyang Institute of Science and Technology, Luoyang 471023, China
}

Received: 23 December 2014

Accepted: 5 March 2015

\begin{abstract}
The bacterial communities of activated sludge from nine wastewater treatment plants (WWTPs) located in three cities in China were examined using high-throughput MiSeq sequencing. The results showed that there were 57 genera of bacterial populations commonly shared by all nine systems, including Ferruginibacter, Dechloromonas, Zoogloea, Gp4, Gp6, etc., indicating that there was a core microbial community in the microbial populations of WWTPs at different geographic locations. Canonical correspondence analysis (CCA) results indicated that the bacterial community variance correlated most strongly with water temperature, dissolved oxygen (DO), concentrations of chemical oxygen demand (COD), and solids retention time (SRT). Variance partitioning analyses suggested that wastewater characteristics had the greatest contribution to the bacterial community variance, explaining $21 \%$ of the variance of bacterial communities independently, followed by operational parameters (17\%), and geographic location (11\%). This study provided insights into the diversity and bacterial community structures in geographically distributed WWTPs.
\end{abstract}

Keywords: wastewater treatment plant, bacterial community structure, MiSeq, canonical correspondence analysis (CCA)

\section{Introduction}

The biologically activated sludge process is the most widely used biological process to treat municipal and industrial wastewater. The efficient and stable operation of a biological wastewater treatment plant (WWTP) depends on the relative abundance or activity of the microbial populations within it $[1,2]$. Despite the environmental importance of these processes, the knowledge of the microbial communities within biological wastewater treatment is incomplete, primarily because of a lack of suitable tools for their analysis [3]. Culture-dependent methods have some limitations because they do not permit the retrieval of most of the bacteria present in complex communities and hence

*e-mail: wenyun_2014@126.com give a poor understanding of microbial community structure $[4,5]$. The development of conventional molecular techniques in the last two decades, such as fluorescence in situ hybridization (FISH), denaturing gradient gel electrophoresis (DGGE), clone libraries, etc., have provided new insights into microbial community structure. However, these methods generally have difficulty detecting most of the low-abundance microorganisms in a activated sludge microbial community, thus providing incomplete information about the microbial diversity and community structure within the biological WWTPs [3].

Recently developed high-throughput sequencing technology such as pyrosequencing and Illumina have significantly improved researchers' ability to investigate the lowabundance microorganisms, and therefore can elucidate the characters of microbial community more completely and 
Table 1. Characteristics of nine wastewater treatment plants.

\begin{tabular}{|c|c|c|c|c|c|c|c|c|c|c|c|c|c|}
\hline \multirow{2}{*}{$\sum^{\infty}$} & \multicolumn{3}{|c|}{ Location } & \multirow{2}{*}{$\frac{0}{\tilde{J}}$} & \multirow{2}{*}{ 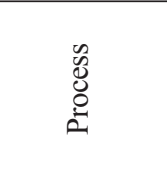 } & \multirow{2}{*}{ ○ิ } & \multirow{2}{*}{ 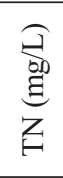 } & \multirow{2}{*}{ 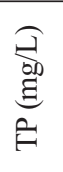 } & \multirow{2}{*}{$\stackrel{I}{2}$} & \multirow{2}{*}{ 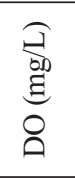 } & \multirow{2}{*}{ 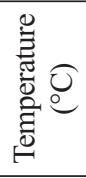 } & \multirow{2}{*}{$\begin{array}{l}\hat{\sigma} \\
\frac{\sqrt{n}}{\omega}\end{array}$} & \multirow{2}{*}{ 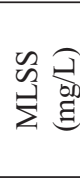 } \\
\hline & City & Latitude & Longitude & & & & & & & & & & \\
\hline A1 & Guangzhou & 23.11 & 113.35 & plant & $\mathrm{AB}$ & 375 & 42 & 6.1 & 6.17 & 2.88 & 20.3 & 20 & 3996 \\
\hline $\mathrm{A} 2$ & Guangzhou & 23.05 & 113.23 & plant & $\mathrm{A}^{2} \mathrm{O}$ & 319 & 43 & 5.7 & 6.34 & 3.72 & 21.1 & 18 & 4732 \\
\hline A3 & Guangzhou & 23.12 & 113.22 & plant & $\mathrm{A}^{2} \mathrm{O}$ & 358 & 57 & 5.4 & 6.57 & 3.65 & 20.9 & 15 & 3657 \\
\hline B1 & LuoYang & 34.64 & 112.41 & plant & $\mathrm{A}^{2} \mathrm{O}$ & 519 & 52 & 6.1 & 6.51 & 3.71 & 17.1 & 15 & 3956 \\
\hline B2 & LuoYang & 34.65 & 112.32 & plant & $\mathrm{A}^{2} \mathrm{O}$ & 475 & 47 & 7.2 & 7.09 & 4.16 & 17.2 & 15 & 4912 \\
\hline B3 & LuoYang & 34.59 & 112.37 & plant & $\begin{array}{c}\text { Oxidation } \\
\text { ditch }\end{array}$ & 463 & 51 & 6.9 & 6.92 & 3.72 & 17.4 & 18 & 3345 \\
\hline $\mathrm{C} 1$ & Beijing & 40.02 & 116.29 & plant & $\mathrm{A}^{2} \mathrm{O}$ & 484 & 56 & 6.1 & 7.15 & 2.87 & 16.6 & 15 & 4183 \\
\hline $\mathrm{C} 2$ & Beijing & 40.04 & 116.36 & plant & $\mathrm{A}^{2} \mathrm{O}$ & 464 & 61 & 6.1 & 7.28 & 3.14 & 16.7 & 15 & 4036 \\
\hline $\mathrm{C} 3$ & Beijing & 40.32 & 116.63 & plant & $\mathrm{A}^{2} \mathrm{O}+\mathrm{MBR}$ & 412 & 52 & 6.2 & 7.37 & 4.93 & 16.8 & 20 & 5200 \\
\hline
\end{tabular}

$\mathrm{AB}$ - Absorption biodegradation, $\mathrm{A}^{2} \mathrm{O}$ - Anaerobic/Anoxic/Aerobic, $\mathrm{MBR}$ - Membrane bioreactor

accurately $[6,7]$. Illumina MiSeq, developed by Illumina Inc., can generate several gigabases of DNA sequence per run - more than other high-throughput sequencing technology. This new technique has been extended to various environmental systems in recent years [8-12]. However, to our knowledge only a very limited number of studies have used Illumina MiSeq technology to examine the microbial community structures in WWTPs. Also, these early studies only focused on the microbial communities in a single wastewater treatment system [13] and did not examine the relationships between microbial community structures and environmental variables, thus it is not clear how wastewater characteristics, operational parameters, and geographic locations influence the bacterial community structures.

To examine the diversity and abundance of bacteria in wastewater treatment plants located in different geographic regions, and to elucidate how the wastewater characteristics, operational parameters, and geographic locations affect the bacterial community structures, we collected nine activated sludge samples from nine municipal WWTPs located in different regions of China and analyzed these samples via MiSeq technology to obtain the bacterial community structures and diversities.

\section{Materials and Methods}

\section{WWTPs and Sampling}

Activated sludge samples were collected from the aeration tanks of nine full-scale wastewater treatment plants located at different geographic cities of China: Guangzhou, Luoyang, and Beijing. Details of the locations, treatment processes, influent, and operational parameters of the nine systems are listed in Table 1. The nine systems were operated using different treatment processes: oxidation ditch, anaerobic/anoxic/aerobic $\left(\mathrm{A}^{2} \mathrm{O}\right)$, membrane bioreactor (MBR), and absorption biodegradation (AB) (Table 1).
Activated sludge samples were collected from the aeration tanks of nine wastewater treatment plants in winter 2012. For archiving, each sample of $40 \mathrm{~mL}$ was dispensed into a $50 \mathrm{~mL}$ sterile Eppendorf tube and centrifuged at $14,000 \mathrm{~g}$ for $10 \mathrm{~min}$. The supernatant was decanted, and the pellet was stored at $-80^{\circ} \mathrm{C}$ prior to analysis [14]. Meanwhile, various chemical parameters such as COD, total nitrogen (TN), ammonia, total phosphorus (TP), and $\mathrm{pH}$ were analyzed according to standard methods [15].

\section{DNA Extraction and PCR Amplification}

Microbial genomic DNA was extracted using a FastDNA SPIN Kit for Soil (MP Biotechnology, Illkirch, France) according to the manufacturer's protocol. Before sequencing, the extracted DNA samples were amplified with a set of primers targeting the hypervariable V4 region of the 16S rRNA gene. The forward primer is 5'-GTGCCAGCMGCCGCGG-3' and the reverse primer is 5'-GGACTACHVGGGTWT CTAAT-3'. Barcode and adapter were incorporated between the adapter and the forward primers. The PCR amplification was conducted in a $20-\mu \mathrm{L}$ reaction system containing $4 \mu \mathrm{L} 5 \times$ FastPfu Buffer, $2 \mu \mathrm{L} 2.5 \mathrm{mM}$ dNTPs, $0.4 \mu \mathrm{L}$ Forward Primer $(5 \mu \mathrm{M})$, $0.4 \mu \mathrm{L}$ Reverse Primer ( $5 \mu \mathrm{M}), 0.4 \mu \mathrm{L}$ Fastfu Polymerase, and 10 ng Template DNA. The PCR was performed under the following conditions: $95^{\circ} \mathrm{C}$ for $2 \mathrm{~min}, 30$ cycles of $95^{\circ} \mathrm{C}$ for $30 \mathrm{~s}, 55^{\circ} \mathrm{C}$ for $30 \mathrm{~s}, 72^{\circ} \mathrm{C}$ for $30 \mathrm{~s}$, and a final extension at $72^{\circ} \mathrm{C}$ for $5 \mathrm{~min}$. PCR products were purified using a QIAquick PCR Purification Kit (Qiagen, Germany).

\section{MiSeq Sequencing}

About 500 ng of purified PCR product for each sample was mixed and sent to a commercial company (Majorbio, Shanghai, China) for MiSeq sequencing. After sequencing, Python scripts were written to perform quality filtering of the raw reads as follows: 
Table 2. Bacterial diversity indices from nine systems.

\begin{tabular}{|c|c|c|c|c|}
\hline WWTPs & $\begin{array}{c}\text { No. of } \\
\text { sequences }^{\mathrm{a}}\end{array}$ & Richness $^{\mathrm{b}}$ & $\mathrm{H}^{\mathrm{c}}$ & Evenness $^{\mathrm{d}}$ \\
\hline $\mathrm{A} 1$ & 34567 & 2248 & 8.07 & 0.72 \\
\hline A2 & 28541 & 2793 & 8.66 & 0.79 \\
\hline A3 & 40124 & 2659 & 8.41 & 0.78 \\
\hline B1 & 33251 & 3126 & 8.87 & 0.88 \\
\hline B2 & 31258 & 2546 & 8.12 & 0.76 \\
\hline B3 & 33657 & 2893 & 8.62 & 0.81 \\
\hline C1 & 48321 & 3012 & 8.86 & 0.86 \\
\hline C2 & 23422 & 2547 & 8.21 & 0.77 \\
\hline C3 & 34652 & 2961 & 8.74 & 0.83 \\
\hline
\end{tabular}

${ }^{a}$ Detected sequence number, ${ }^{b}$ Detected OTU number, ${ }^{\mathrm{c} S h a n n o n-}$ Wiener index, ${ }^{\mathrm{d}}$ Evenness index.

1) to sort sequences exactly matching the specific barcodes into different samples,

2) to check sequencing quality by filtering out the reads with any uncalled bases or two-paired end reads with less than 80 bases overlapping,

3) to trim off the barcodes and primers.

Taxonomic classifications of the effective sequences were carried out using the RDP Classifier (Version 2.4) with a set confidence threshold of $80 \%$ to assign the sequences to different taxonomy levels. The raw reads have been deposited into the NCBI short-reads archive database (Accession Number: SRR1178945).

\section{Data Analysis}

The Shannon-Wiener index was performed to assess bacterial diversity using R 2.14.0 (R Development Core Team, 2011) with a $3 \%$ cutoff in nucleic acid sequences. Canonical correspondence analysis (CCA) was used to examine the relationships of bacterial communities and environmental variables. The significant environmental variables were identified by a forward selection procedure using Monte Carlo permutations (999 permutations with a p-value of 0.05). In addition, Variance inflation factors (VIFs; a measure for cross-correlation of explanatory variables) were checked and eliminated if VIFs were more than 20. Based on partial CCA, variance partitioning analysis (VPA) was performed to attribute the variation observed in the bacterial communities to the environmental variables. CCA and VPA were performed by the vegan package in R 2.14.0 (R Development Core Team, 2011).

\section{Results and Discussion}

\section{The Composition of Bacterial Community}

As shown in Table 2, after filtering the low-quality reads, there were $23,422-48,321$ effective reads for nine activated sludge samples; the library size of each sample was then normalized to 23,422 sequences, which was the lowest number of sequences among the nine samples. An RDP classifier was used to assign these sequence tags into different OTUs with $3 \%$ of nucleotide cutoff.

A total of 8,194 OTUs were recovered from the nine activated sludge samples. Individual samples contained a much smaller number of OTUs (from 2,248 to 3,126; Table 2). To assess the internal (within-sample) complexity of individual microbial populations, Shannon-Wiener index $\mathrm{H}$ ) and Evenness were calculated. The values of $\mathrm{H}$ ranged from 8.07 to 8.87 across the nine samples. The evenness of all samples showed little differences ranging from 0.72 to 0.88 (Table 2).

Fig. 1a summarizes the relative bacterial community abundance at the phylum level for each sample. Proteobacteria was the predominant phylum, constituting between 22 and $48 \%$ of all detected OTUs. Bacteroidetes, Acidobacteria, Chloroflexi, and Verrucomicrobia were the subdominant groups, each containing 16-39\%, 2-22\%, $1-14 \%$, and $0-10 \%$ of the detections, respectively.

Within Proteobacteria, $\beta$-Proteobacteria was the most dominant group (31-50\%), followed by $\gamma$-Proteobacteria (7-43\%), $\alpha$-Proteobacteria (8-30\%), and $\delta$-Proteobacteria $(4-17 \%)$ (Fig. 1b). Within the $\beta$-Proteobacteria, Rhodocyclales is the dominant group within a range of 22$42 \%$ of all nine samples, followed by Burkholderiales and Gallionellales, representing $12-26 \%$ and $7-22 \%$ of each population, respectively. The abundance of $\beta$-Proteobacteria observed in this study agrees with the previous results $[16,17]$.

\section{Core and Unique Families and Genera}

In this study, a total of 137 families were obtained. 46 families (accounting for 79-91\% of the classified sequences), including Anaerolineaceae, Rhodocyclaceae, Chitinophagaceae, Xanthomonadaceae, Verrucomicrobiaceae, Hyphomicrobiaceae, Planctomycetaceae, Saprospiraceae, Fusobacteriales, etc., were commonly shared by all samples. There were 16 rare families that only appeared in one sample, such as Ectothiorhodospiraceae, Methanocorpusculaceae, Sanguibacteraceae, Pseudonocardiaceae, Nakamurellaceae, Sporichthyaceae, etc., which occupied only $<1 \%$ of the classified sequences.

At the genera level, 496 genera were acquired from all samples. Among them, 57 were shared by all nine samples, and accounted for $59-82 \%$ of the classified sequences. There were 116 rare genera that were only observed in one sample, and accounted for $<0.5 \%$ of total classified sequences in each sample. There were five genera that were abundant $(>1 \%)$ in all nine samples, including Ferruginibacter, Dechloromonas, Zoogloea, Gp4, and Gp6. Most of them were also found to be core genera and shared by multiple activated samples from WWTPs by Zhang et al. [18] and Wang et al. [3]

These results indicated that these core genera may play crucial roles for wastewater treatment regardless of treatment process and geographic location. Members of 
Ferruginibacter, such as Ferruginibacter alkalilentus and Ferruginibacter lapsinanis, are capable of hydrolyzing some organic matter [19]. Dechloromonas is a genus capable of reducing perchlorate and also frequently reported as phosphate accumulating organisms in biological wastewater treatment systems [16, 20]. Members of Zoogloea, such as Zoogloea ramigera, have long been considered as the typical activated sludge bacteria responsible for the formation of activated sludge flocculation and improve the purification process [19]. The genera of Gp4 and Gp6 are not well described, and their knowledge and roles in biological WWTPs are limited. This result was in accordance with the findings of Xia et al. [17], who found that, based on examining bacterial community structures in WWTPs via PhyloChip, five different wastewater treatment reactors share a large proportion of core bacterial population.

\section{Relationship of Environmental Factors to the Bacterial Communities}

CCA was performed to correlate environmental factors with bacterial community structures and determine major environmental variables in shaping the bacterial community structures. Based on variance inflation factors (VIF) with 999 Monte Carlo permutations, four significant environmental variables were selected: water temperature, dissolved oxygen (DO), influent concentrations of chemical oxygen demand (COD), and solid retention time (SRT) (Fig. 2). The length of an environmental parameter arrow in the ordination plot indicates the strength of the relationship of that parameter to community composition. As such, temperature, DO, COD, and SRT appear to be the most important environmental parameters.
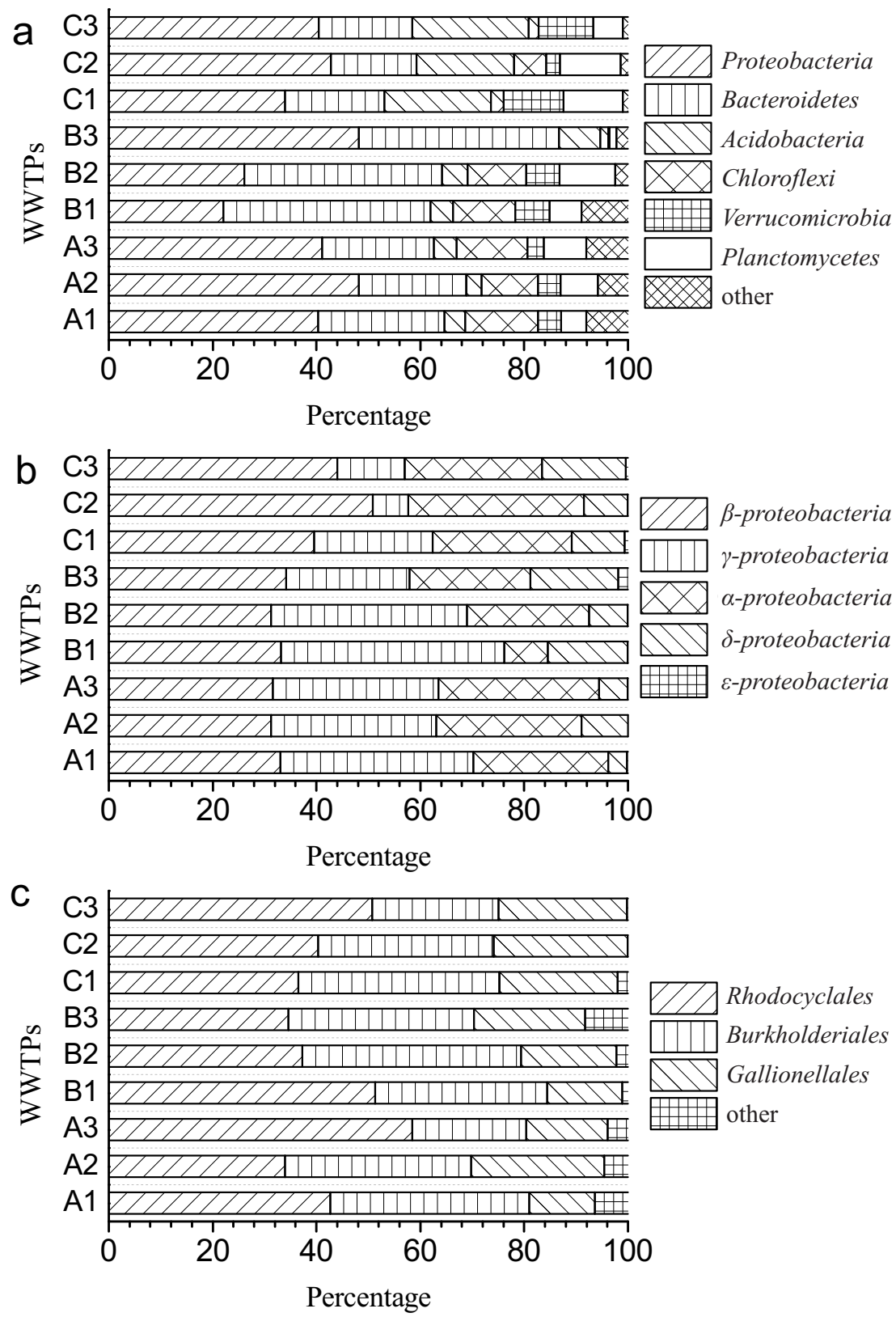

Fig. 1. Relative abundance of bacterial community composition in nine samples: a) the relative abundance of total bacteria grouped by phyla, b) relative abundance of the phylum Proteobacteria, and c) relative abundance of the $\beta$-proteobacteria. 


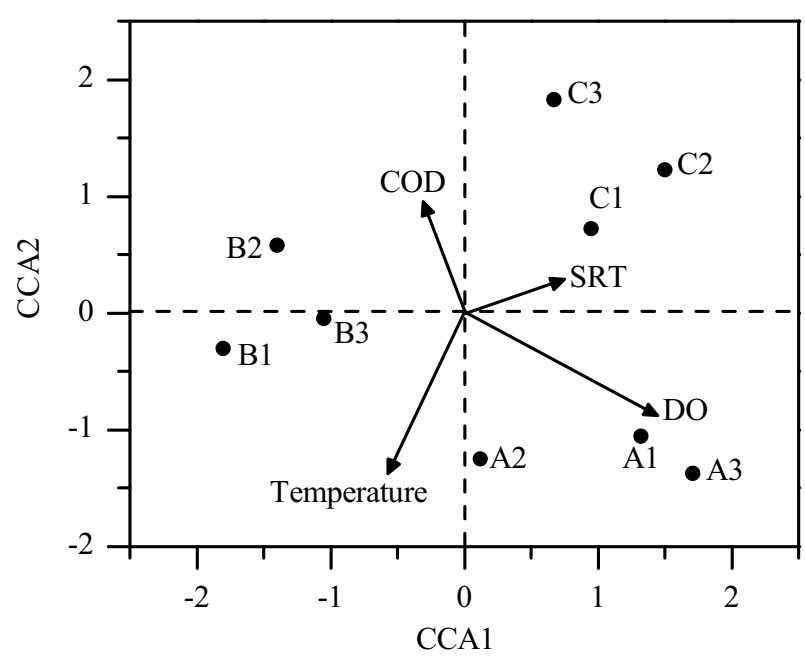

Fig. 2. Canonical correspondence analysis (CCA) of MiSeq data and environmental variables in the nine samples. Arrows indicate the direction and magnitude of environmental variables associated with bacteria community structures. Each circle represents a different bacteria community structure from a specific wastewater treatment plant.

In this study, water temperature was an important variable influencing bacterial community structures. This agrees with the findings of Hai et al. [1], who suggested - based on the survey of temporal variation of bacterial taxa in a fulland lab-scale activated sludge bioreactor via pyrosequencing of $16 \mathrm{~S}$ rRNA genes - that water temperature is one of the most influential factors on bacterial community variance. Ebrahimi et al. [21] found that, in two sequencing batch reactors (SBR) operated at $20^{\circ} \mathrm{C}, 30^{\circ} \mathrm{C}$, and $35^{\circ} \mathrm{C}$, bacterial richness and diversity were clearly altered. Several other studies also demonstrated that temperature imposed a strong selective pressure on bacterial communities of activated sludge [22-25]. As with temperature, DO was also strongly and significantly linked to bacterial community variance in CCA analyses. DO is well recognized as a critical process parameter in biological wastewater treatment processes due to its impact on bacterial activity and the high operational costs of aeration. The results of this study showed that DO had a significant effect in shaping the bacterial community structure in wastewater treatment systems. Park et al. [26] have also demonstrated, in two lab-scale bioreactors with different DO concentrations, that DO concentration was an important influential factor based on the T-RFLP analysis of bacterial community structures. In addition to temperature and influent $\mathrm{OD}$, bacterial community variance was also significantly linked to the COD concentrations in the WWTPs in CCA analysis. COD provides carbon and energy sources to heterotrophic bacteria and influences the growth rate of the bacteria [27]. Previous studies have shown that COD (or organic loading) was a crucial factor to shape the bacterial community structures $[1,22]$.

Variance partitioning analyses (VPA) was further performed to assess the contributions of wastewater characteristics (COD, TN, TP, $\mathrm{pH}$ ), operational parameters (DO, temperature, SRT, mixed liquid suspended solids (MLSS)), and geographic locations to the microbial community variance. Fig. 3 indicated that $54 \%$ of the variance could be explained by these three components. Wastewater characteristics, operational parameters, and geographic locations could independently explain $21 \%, 17 \%$, and $11 \%$ of the variation of bacterial communities, respectively. Interactions among the three major components seemed to have less influence than did individual components.

About $46 \%$ of the community variance could not be explained by these three components. It is reasonable to expect that some unmonitored wastewater and operational factors may play an influential role in shaping bacterial community structures in WWTPs. In addition to the deterministic environmental factors, the neutral factors may also affect the bacterial community structure. Ofiteru et al. [28] a)

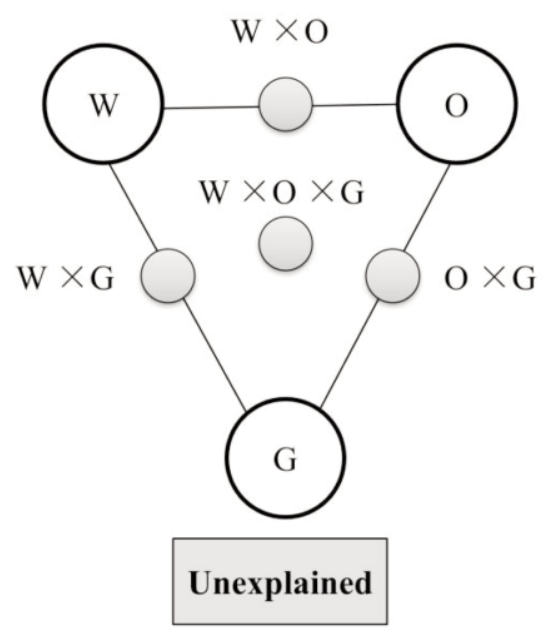

b)

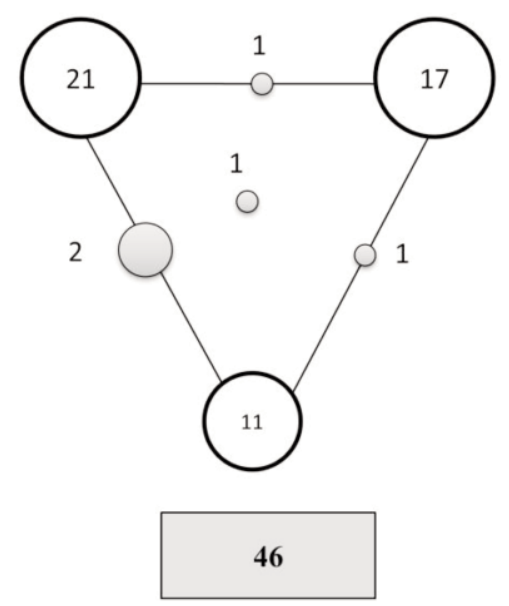

Fig. 3. Variation partitioning analysis of microbial community explained by wastewater characteristics (W), operational parameters $(\mathrm{O})$, and geographic location $(\mathrm{G})$. (a) General outline, (b) bacterial communities. Each diagram represents the biological variation partitioned into the relative effects of each factor or a combination of factors in which geometric areas were proportional to the respective percentages of explained variation. The edges of the triangle presented the variation explained by each factor alone. The sides of the triangles presented interactions of any two factors and the middle of the triangles represented interactions of all three factors. 
suggested that the variation of bacterial community in a full-scale WWTP was consistent with neutral community assembly, where chance and random immigration played an important and predictable role in shaping the communities. Ayarza and Erijman [29] illustrated, in four activated sludge bioreactors, that both deterministic and neutral effects operated simultaneously in the assembly of bacterial communities. Similar results were also observed in other studies [3032]. The relative influence of deterministic and stochastic factors in structuring microbial communities within bioreactors warrants future investigation.

In summary, high-throughput MiSeq sequencing was used to investigate the bacterial communities of activated sludge samples from nine WWTPs located in three cities in China. In addition to certain unique genera of bacterial populations in each sample, 57 genera, including genera of Ferruginibacter, Dechloromonas, Zoogloea, Gp4, and Gp6, etc., were commonly shared by all samples. This demonstrated that there was a core bacterial community in the microbial populations of WWTPs at different locations. The CCA results illustrated that water temperature, $\mathrm{DO}, \mathrm{COD}$, and SRT were correlated most strongly to the variance of bacterial communities. VPA results indicated that wastewater characteristics had the greatest contribution to the bacterial community variance, explaining $21 \%$ of the variance of bacterial communities independently, followed by operational parameters (17\%) and geographic locations (11\%). These findings provided insights into the diversity and bacterial community structures in geographically distributed WWTPs and identified the main factors structuring microbial communities in WWTPs.

\section{Acknowledgements}

This study was supported by the Key Technologies R \& D Program of Henan Province (132102210187).

\section{References}

1. HAI R. T., WANG Y. L., WANG X. H., LI Y., DU Z. Z. Bacterial Community Dynamics and Taxa-Time Relationships within Two Activated Sludge Bioreactors. Plos One 9, 2014.

2. GENTILE M. E., JESSUP C. M., NYMAN J. L., CRIDDLE C. S. Correlation of functional instability and community dynamics in denitrifying dispersed-growth reactors. Appl. Environ. Microb. 73, 680, 2007.

3. WANG X., HU M., XIA Y., WEN X., DING K. Pyrosequencing analysis of bacterial diversity in 14 wastewater treatment systems in china. Appl. Environ. Microb. 78, 7042, 2012.

4. GILBRIDE K. A., LEE D. Y., BEAUdetTE L. A. Molecular techniques in wastewater: Understanding microbial communities, detecting pathogens, and real-time process control. J. Microbiol. Meth. 66, 1, 2006.

5. WANG X., WEN X., CRIDDLE C., YAN H., ZHANG Y., DING K. Bacterial community dynamics in two full-scale wastewater treatment systems with functional stability. J. Appl. Microbiol. 109, 1218, 2010.
6. HU M., WANG X., WEN X., XIA Y. Microbial community structures in different wastewater treatment plants as revealed by 454-pyrosequencing analysis. Bioresource Technol. 117, 72, 2012.

7. ROESCH L. F., FULTHORPE R. R., RIVA A., CASELLA G., HADWIN A. K. M., KENT A. D., DAROUB S. H., CAMARGO F. A. O., FARMERIE W. G., TRIPLETT E. W. Pyrosequencing enumerates and contrasts soil microbial diversity. ISME. J. 1, 283, 2007.

8. CAPORASO J. G., LAUBER C. L., WALTERS W. A., BERG-LYONS D., HUNTLEY J., FIERER N., OWENS S. M., BETLEY J., FRASER L., BAUER M., GORMLEY N., GILBERT J. A., SMITH G., KNIGHT R. Ultra-highthroughput microbial community analysis on the Illumina HiSeq and MiSeq platforms. ISME. J. 6, 1621, 2012.

9. GIBSON J., SHOKRALLA S., PORTER T. M., KING I., VAN KONYNENBURG S., JANZEN D. H., HALLWACHS W., HAJIBABAEI M. Simultaneous assessment of the macrobiome and microbiome in a bulk sample of tropical arthropods through DNA metasystematics. Proc. Natl. Acad. Sci. USA. 111, 8007, 2014.

10. LI Y., HE J., HE Z., ZHOU Y., YUAN M., XU X., SUN F., LIU C., LI J., XIE W., DENG Y., QIN Y., VANNOSTRAND J. D., XIAO L., WU L., ZHOU J., SHI W., ZHOU X. Phylogenetic and functional gene structure shifts of the oral microbiomes in periodontitis patients. ISME. J., 2014.

11. LIANG B., CHENG H., VAN NOSTRAND J. D., MA J., YU H., KONG D., LIU W., REN N., WU L., WANG A., LEE D. J., ZHOU J. Microbial community structure and function of Nitrobenzene reduction biocathode in response to carbon source switchover. Water Res. 54C, 137, 2014.

12. LIANG B., CHENG H., VAN NOSTRAND J. D., MA J., YU H., KONG D., LIU W., REN N., WU L., WANG A., LEE D.-J., ZHOU J. Microbial community structure and function of Nitrobenzene reduction biocathode in response to carbon source switchover. Water Res. 54, 137, 2014.

13. SANAPAREDDY N., HAMP T. J., GONZALEZ L. C., HILGER H. A., FODOR A. A., CLINTON S. M. Molecular Diversity of a North Carolina Wastewater Treatment Plant as Revealed by Pyrosequencing. Appl. Environ. Microb. 75, 1688, 2009.

14. WANG X. H., WEN X. H., CRIDDLE C., WELLS G., ZHANG J., ZHAO Y. Community analysis of ammonia-oxidizing bacteria in activated sludge of eight wastewater treatment systems. J. Environ. Sci.-China 22, 627, 2010.

15. APHA. Standard Methods for the Examination of Water and Waste Water. $2^{\text {th }}$ ed. APHA, Washington DC, USA, 2012.

16. ZHANG T., SHAO M. F., YE L. 454 Pyrosequencing reveals bacterial diversity of activated sludge from 14 sewage treatment plants. ISME. J. 6, 1137, 2012.

17. XIA S. Q., DUAN L. A., SONG Y. H., LI J. X., PICENO Y. M., ANDERSEN G. L., ALVAREZ-COHEN L., MORENO-ANDRADE I., HUANG C. L., HERMANOWICZ S. W. Bacterial Community Structure in Geographically Distributed Biological Wastewater Treatment Reactors. Environ. Sci. Technol. 44, 7391, 2010.

18. ZHANG G., ZHAO Q., JIAO Y., WANG K., LEE D. J., REN $\mathrm{N}$. Efficient electricity generation from sewage sludge using biocathode microbial fuel cell. Water Res. 46, 43, 2012.

19. LIM J. H., BAEK S. H., LEE S. T. Ferruginibacter alkalilentus gen. nov., sp. nov. and Ferruginibacter lapsinanis sp. nov., novel members of the family 'Chitinophagaceae' in the phylum Bacteroidetes, isolated from freshwater sediment. Int J Syst Evol Microbiol 59, 2394, 2009. 
20. LIU Y., ZHANG T., FANG H. H. P. Microbial community analysis and performance of a phosphate-removing activated sludge. Bioresource Technol. 96, 1205, 2005.

21. EBRAHIMI S., GABUS S., ROHRBACH-BRANDT E., HOSSEINI M., ROSSI P., MAILLARD J., HOLLIGER C. Performance and microbial community composition dynamics of aerobic granular sludge from sequencing batch bubble column reactors operated at $20 \mathrm{~A}$ degrees $\mathrm{C}, 30 \mathrm{~A}$ degrees C, and 35 A degrees C. Appl. Microbiol. Biot. 87, $1555,2010$.

22. WANG X., XIA Y., WEN X., YANG Y., ZHOU J. Microbial Community Functional Structures in Wastewater Treatment Plants as Characterized by GeoChip. Plos One 9, e93422, 2014.

23. LI T., BO L., YANG F., ZHANG S., WU Y., YANG L. Comparison of the removal of COD by a hybrid bioreactor at low and room temperature and the associated microbial characteristics. Bioresource Technol. 108, 28, 2012.

24. SZUKICS U., ABELL G. C. J., HODL V., MITTER B., SESSITSCH A., HACKL E., ZECHMEISTERBOLTENSTERN S. Nitrifiers and denitrifiers respond rapidly to changed moisture and increasing temperature in a pristine forest soil. Fems Microbio.l Ecol. 72, 395, 2010.

25. SIGGINS A., ENRIGHT A. M., O'FLAHERTY V. Temperature dependent (37-15 degrees C) anaerobic digestion of a trichloroethylene-contaminated wastewater. Bioresource Technol. 102, 7645, 2011.
26. PARK H. D., NOGUERA D. R. Evaluating the effect of dissolved oxygen on ammonia-oxidizing bacterial communities in activated sludge. Water Res. 38, 3275, 2004.

27. KIM T.-S., JEONG J.-Y., WELLS G. F., PARK H.-D. General and rare bacterial taxa demonstrating different temporal dynamic patterns in an activated sludge bioreactor. Appl. Microbiol. Biot. 97, 1755, 2013.

28. OFITERU I. D., LUNN M., CURTIS T. P., WELLS G. F., CRIDDLE C. S., FRANCIS C. A., SLOAN W. T. Combined niche and neutral effects in a microbial wastewater treatment community. Proc. Natl. Acad. Sci. USA. 107, 15345, 2010.

29. AYARZA J. M., ERIJMAN L. Balance of Neutral and Deterministic Components in the Dynamics of Activated Sludge Floc Assembly. Microbial Ecol. 61, 486, 2011.

30. CURTIS T. P., SLOAN W. T. Towards the design of diversity: stochastic models for community assembly in wastewater treatment plants. Water Sci. Technol. 54, 227, 2006.

31. SLOAN W. T., LUNN M., WOODCOCK S., HEAD I. M., NEE S., CURTIS T. P. Quantifying the roles of immigration and chance in shaping prokaryote community structure. Environ. Microbiol. 8, 732, 2006.

32. GRAHAM D. W., KNAPP C. W., VAN VLECK E. S., BLOOR K., LANE T. B., GRAHAM C. E. Experimental demonstration of chaotic instability in biological nitrification. ISME. J. 1, 385, 2007. 
